\title{
Anti-inflammatory properties of mangosteen peel extract on the mice gingival inflammation healing process
}

\author{
Khairani Putri*, Lusiana Darsono*, Henry Mandalas** \\ *Department of Microbiology Faculty of Dentistry Maranatha Christian University, Indonesia \\ **Department of Periodontics Faculty of Dentistry Maranatha Christian University, Indonesia
}

\begin{abstract}
Introduction: Mangosteen (Garcinia Mangostana L.) peel extract has widely used in the pharmaceutical field due to its anticancer, anti-inflammatory, antibacterial, and immunity boost properties. It had been proofed to be able to prevent and reduce the amount of plaque and cure gingivitis. This study was aimed to compare mangosteen peel extract at the concentration of 12.5 and $25 \%$ on the mouse gingival inflammation healing process. Methods: This study was a true experimental laboratory study. The subjects consisted of 28 mice divided into four groups, which were negative control (Aquadest) group; positive control ( $0.2 \%$ of Chlorhexidine) group; $12.5 \%$ Group of mangosteen peel extract group; and $25 \%$ respectively. Examination of the inflammatory healing process was observed every 2 hours during 6 hours, and the inflammatory measurements of mouse gingival performed by using calipers. Data obtained was analyzed with the one-way ANOVA test $(a=0.05)$ and the Tukey's range test. Results: The results from the one-way ANOVA test and the Tukey's range test found that there was a significant difference on the inflammation size between the group with $12.5 \%$ of mangosteen peel extract and the group with aquadest and $0.2 \%$ of chlorhexidine. Meanwhile, the mice group with $12.5 \%$ of mangosteen peel extract and group with $25 \%$ of mangosteen peel extract did not show a significant difference in inflammatory size decrease. Conclusion: The mangosteen peel extract at the concentration of $12.5 \%$ was showing the highest anti-inflammatory potentials since the first measurement on the second hour after treatment.
\end{abstract}

Keywords: Mangosteen (Garcinia Mangostana L.), Aquadest, Chlorhexidine, anti-inflammatory, gingival inflammation

P-ISSN 1979-0201, e-ISSN 2549-6212 Available from:http://jurnal.unpad.ac.id/pjd/article/view/14399

DOI: 10.24198/pjd.vol29no3.14399

Submission: Jun 2017 Publishing: Nov 2017

\section{INTRODUCTION}

Gingivitis is a periodontal inflammation disease caused by bacterial infection as a result of the poor oral hygiene. Gingivitis characterized by changes in the shape, colour, texture, and soreness in the gingiva. ${ }^{1-3}$

Indonesia Dental Association (PDGI) had stated that the prevalence of gingivitis worldwide was in the rate of $75-90 \% .4,5$ While in Indonesia

Corresponding author: Henry Mandalas, Department of Microbiology Faculty of Dentistry Maranatha Christian University Jl. Prof. drg. Surya Sumantri No.65, Bandung, Jawa Barat 40164, Indonesia.Email: h_mandalas@yahoo.com 
gingivitis was ranked the second most common oral disease, reaching the rate of $96.58 \%$. The Basic Health Research (RISKESDAS) in 2007 had mentioned that periodontal disease in West Java was the fifth largest throughout Indonesia, which was in the rate of $25.3 \% .^{5}$ Patients who have gingivitis often complains clinical signs such as bleeding gingiva or bleeding after brushing or flossing. Various things can cause this symptom. Plaque and calculus accumulated on the tooth surface is the most common cause. If not treated immediately will dislodge the gingival tissues attachment to the tooth surface and formed periodontal pockets, and also will be able to damage the tooth's supporting bone. ${ }^{6}$

One way to treat gingivitis is by using of herbal extracts, such as the mangosteen (Garcinia Mangostana L.) peel extract, due to its main compound called xanthone. Xanthone compounds contained the $a$-mangostin and the $\gamma$-mangostin which has antibacterial and anti-inflammatory properties. Xanthone plays an important role in the cessation of inflammation by inhibiting the production of cyclooxygenase (COX) enzymes that are responsible for formation of the inflammation. ${ }^{2}$

The results of the research conducted by Yulia $^{7}$ in 2013 stated that the mangosteen peel extract contains xanthone compounds that have been proven to have anti-inflammatory activity and very high antioxidant activity. The pathogenesis of inflammation occurred due to an increase in inflammatory cells that played an important role in the process of phagocytosis and stimulated free radical release. Antiinflammation and antioxidants played an important role in converting the active free radicals to decrease the reactivity and shortening the inflammatory phase into the healing phase. $^{7}$

The study conducted by Arini et al. ${ }^{8}$ on the effectiveness of gargling with stewed mangosteen peel extract discovered that in the concentration of $12.5 \%$, stewed mangosteen peel extract was able to decrease the amount of plaque on the tooth surface, prevented the plaque accumulation, and cured mild gingivitis. Chlorhexidine $0.2 \%$ as a comparator contains $0.2 \%$ of chlorhexidine gluconate, had proven to be antiplaque that was able to treat gingivitis and prevented periodontal abnormalities. The inflammatory measurements were performed at the second, fourth, and sixth hours because the induction of carrageenan to caused edema last for six hours and gradually diminished within 24 hours. ${ }^{9}$ This study was aimed to compare mangosteen peel extract at the concentration of 12.5 and $25 \%$ on the mouse gingival inflammation healing process.

\section{METHODS}

This research was a true experimental laboratory with completely randomized design and analyzed by using the one-way ANOVA method and by Tukey's range test. The experimental animals were adapted for seven days in Pharmacology Laboratory of the Faculty of Medicine Universitas Padjadjaran at Hasan Sadikin Hospital, Bandung, Indonesia.

As much as twenty-eight Wistar rats were grouped randomly into four treatment groups, with each group consisted of 7 rats. The anaesthesia was performed by using a ketamine injected with a dose of $0.3 \mathrm{ml}$ into the rat's thighs. After the rat anaesthetized, as much as $0.5 \mathrm{ml}$ of carrageenan $0.1 \%$ was injected into the rat's gingiva to formed inflammation then waited for 3 hours for maximum inflammation. The 1st group was applied with Aquadest; the 2nd group was applied with Chlorhexidine $0.2 \%$; the 3 rd group was applied $12.5 \%$ of mangosteen peel extract; and the 4th group was applied with $25 \%$ of mangosteen peel extract. The longest inflammatory diameter (in $\mathrm{mm}$ ) of all groups was measured by using the calipers at the second, fourth, and the sixth hour.

\section{RESULTS}

The results of the inflammation measurement were presented in Table 1 , showed a very rapid healing process on the groups of mice given the $12.5 \%$ and $25 \%$ of mangosteen peel extract, whilst the negative control group given aquadest and the positive control given $0.2 \%$ of chlorhexidine did not show a significant healing process. Figure 1 showed the average time of decreasing size of gingival inflammation diameter in each treatment group calculated every two hours.

Before the data were analyzed using one-way ANOVA test, the data was tested using homogeneity test of variance. The results of the homogeneity test were 0.415 , which categorized as a non-homogeneity data. Afterwards, the data were analyzed by using one-way ANOVA test. 
Table 1. The average of the inflammation diameters of each group on the $2^{\text {nd }}, 4^{\text {th }}$, and the $6^{\text {th }}$ hour

\begin{tabular}{ccccc}
\hline \multirow{2}{*}{ Group } & $\begin{array}{c}\text { Inflammatory diameters after the } \\
\text { injection of carrageenans (in mm) }\end{array}$ & $\begin{array}{c}\text { Inflammatory diameters after given the } \\
\text { anti-inflammatory (in mm) }\end{array}$ \\
\cline { 2 - 5 } & $\mathrm{X}_{1}$ & ${\text { The } 2^{\text {nd }} \text { hour }}^{\text {The } 4^{\text {th }} \text { hour }}$ & The $6^{\text {th }}$ hour \\
\hline G (-) & 0.34 & 0.38 & 0.46 & 0.50 \\
G (+) & 0.34 & 0.39 & 0.35 & 0.32 \\
$12.5 \%$ of mangosteen peel extract group & 0.35 & 0.25 & 0.23 & 0.17 \\
25\% of mangosteen peel extract group & 0.38 & 0.30 & 0.24 & 0.16 \\
\hline
\end{tabular}
Notes:

G (-) : : given Aquadest as negative control group

\section{G (+)}

$12.5 \%$ of mangosteen peel extract group $25 \%$ of mangosteen peel extract group
: given $0.2 \%$ of Chlorhexidine as positive control group

: given $12.5 \%$ of mangosteen peel extract

: given $25 \%$ of mangosteen peel extract

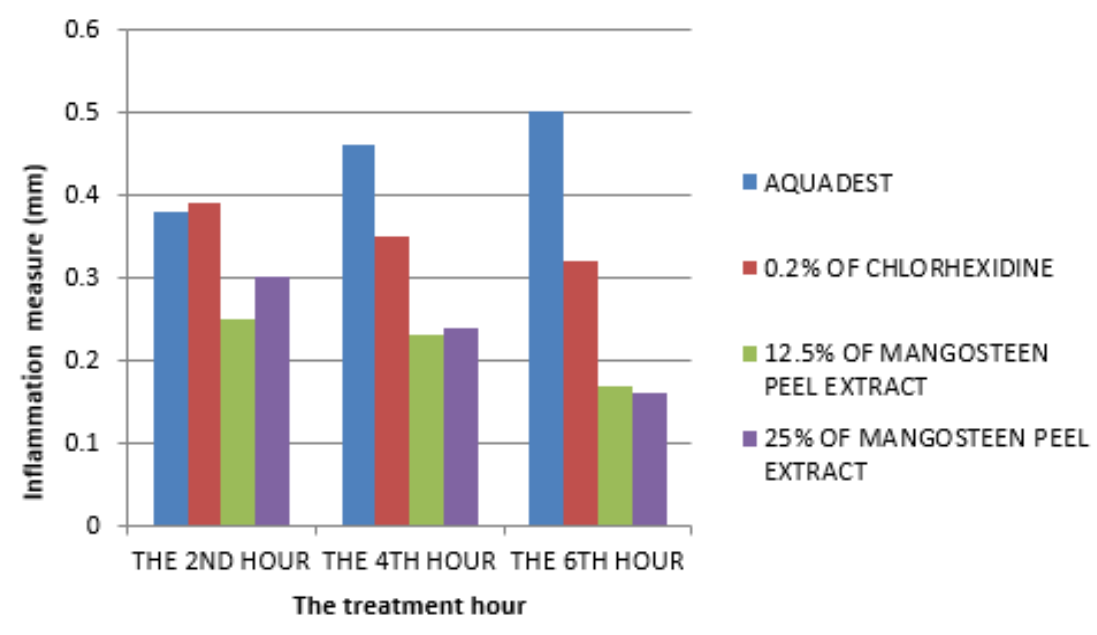

Figure 1. The average of the inflammation measure of each treatment group

The results of the one-way ANOVA test with a significance level $a=0.05$ with the null hypothesis: there was no effect of mangosteen peel extract application on the inflammatory size of all treatment groups, and the alternative hypothesis: there was an effect of mangosteen peel extract application on the inflammatory size of at least one pair of treatment groups. The results of statistical analysis give the following results as presented in Table 2 .

Table 2 showed that the $\mathrm{p}$-value = $0.000(p<0.05)$ which means that there was a significant difference in the inflammatory size of at least one pair of treatment groups. The results of the one-way ANOVA test showed an overall difference between treatment groups, to determine the specific groups differed, the post hoc test using the Tukey's range test was done to confirm where the differences occurred between groups, which presented in Table 3 .
The result of the Tukey's range test on the measurement after 2 hours showed a very significant difference between the control group with the group of $12.5 \%$ of mangosteen peel extract application; a significant difference between the control group with the group of $25 \%$ of mangosteen peel extract application; and no difference between the two treatment groups $(12.5 \%$ and $25 \%$ of mangosteen peel extract applied).

The result of the Tukey's range test on the measurement after 4 hours showed a very significant difference between the negative control group (Aquadest applied) with the positive control group $(0.2 \%$ of Chlorhexidine applied) and the treatment groups; a significant difference between the positive control group with the treatment groups; and no difference between the two treatment groups.

The result of the Tukey's range test on the measurement after 6 hours showed a very 
Table 2. The one-way ANOVA test results on the $2^{\text {nd }}$ hour

\begin{tabular}{ll}
\hline Group & Average value \pm Standard deviation \\
\hline Aquadest & $0.38 \pm 0.0191$ \\
$0.2 \%$ of chlorhexidine & $0.39 \pm 0.046$ \\
$12.5 \%$ of mangosteen peel extract & $0.25 \pm 0.015$ \\
$25 \%$ of mangosteen peel extract & $0.30 \pm 0.044$ \\
p-value & 0.000 \\
\hline
\end{tabular}

Table 3. The Tukey's range test results

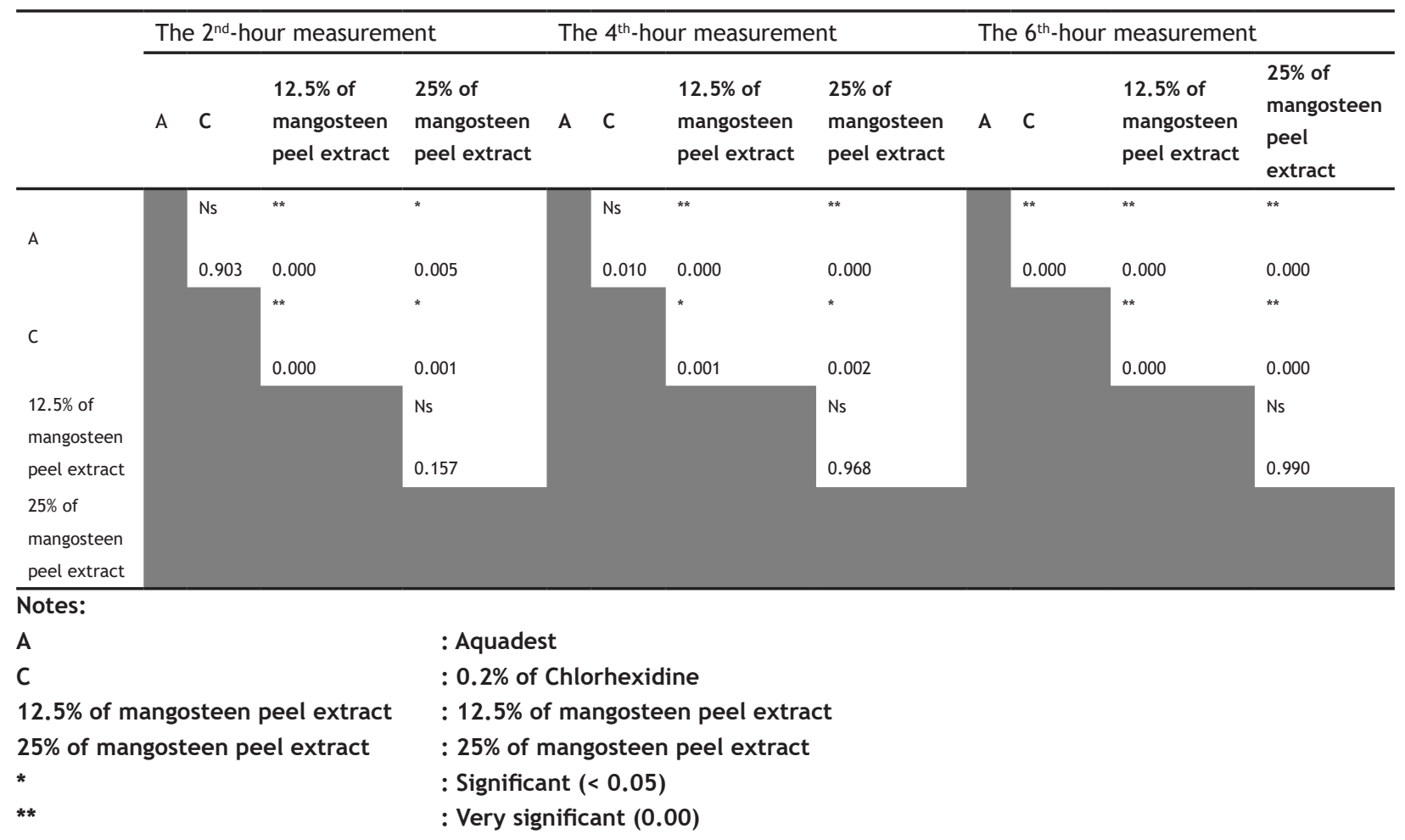

significant difference between the negative and positive control group, and also between the positive control and treatment groups; and no difference between the two treatment groups.

\section{DISCUSSION}

This research was conducted on Wistar rat's inflamed gingiva applied with $12.5 \%$ and $25 \%$ of mangosteen peel extract. At the measurement in the second, fourth, and the sixth hour, there were a very significant difference with the positive control group $(0.2 \%$ of chlorhexidine applied) and negative control group (aquadest applied), whereas no significant difference was found between the two treatment groups $(12.5 \%$ and $25 \%$ of mangosteen peel extract applied). Based on the results above, can be concluded that the mangosteen peel extract at the concentration of $12.5 \%$ was showing the highest anti-inflammatory potentials during the observation in the second, fourth, and the sixth hour.

This result was consistent with the research conducted by Arini et al. ${ }^{8}$ on the effectiveness of gargling with stewed mangosteen peel extract after oral physiotherapy on the gingivitis treatment. From all samples of the treatment group (gargling with stewed mangosteen extract) showed that 14 samples $(87.5 \%)$ were experiencing the full recovery in their gingiva and 2 samples $(12.5 \%)$ were experiencing a severity decrease of gingivitis from moderate to the mild category. Active components contained in the mangosteen peel a-mangostin, B-mangostin, and methoxy-Bmangostin, which were proven efficacious in the gingivitis treatment. ${ }^{8}$ 
On the mangosteen peel contained xanthone substances consisted of the main compounds, namely $\alpha$-mangostin and $\gamma$-mangostin, which proven of having an antioxidant, antibacterial, and anti-inflammatory effect. ${ }^{11,12}$ In addition to xanthone, mangosteen peel also contained tannins and catechins. Tannin is known for having anti-inflammatory, astringent, antidiarrheal, diuretic, and antiseptic properties. Catechin which belongs to the flavonoid group also has anti-inflammatory effect. ${ }^{13}$ Xanthone suppresses the inflammation processes by inhibiting the cyclooxygenase and lipoxygenase enzymes. The inhibition of cyclooxygenase and lipoxygenase enzymes resulting in the release of prostaglandins, prostacyclins, thromboxanes, and leukotrienes that are also suppressing the inflammation processes, marked by a decrease in the number of inflammatory cells. Other compounds in the mangosteen peel that has an anti-inflammatory effect are catechin which belongs to the flavonoid group. The mechanism of flavonoids in suppressing the inflammatory process is by inhibiting the release of arachidonic acid, the secretion of lysosomal enzymes from neutrophil cells and endothelial cells, and inhibits the exudation phase of the inflammation process.

Flavonoids inhibit the release of cyclooxygenase enzyme irreversibly (prostaglandin synthetase), which catalyzes the converting of arachidonic acid into endoperoxide compounds, which will decrease the formation of prostaglandins and suppress the inflammatory process. Suppression of the inflammation process resulting in a decreasing number of the neutrophil cells. Thus, the mangosteen peel extract is proven to be effective for the gingival inflammation treatment. ${ }^{14}$ As inflammation entering the healing phase, the fibroblasts will migrate immediately into the lesions, proliferate, and produce collagen matrices to repair damaged tissues. Fibroblasts are the cellular elements that are commonly found in the lesions healing phase and the tissue repair. ${ }^{15}$

\section{CONCLUSION}

The mangosteen peel extract at the concentration of $12.5 \%$ was showing the highest anti-inflammatory potentials since the first measurement on the second hour after treatment.

\section{REFERENCES}

1. Utami ET, Kuncoro RA, Hutami IR, Sari FT, Handajani J. Antiinflammation effect of Skunkvine (Paederia scandens) extract in Wistar rat. Trad Med J 2011:16(2):95-100.

2. Sumerti NN, Swastini IGAAP, Gejir IN. Efektivitas berkumur air rebusan kulit buah manggis untuk penyembuhan gingivitis pada pasien pasca scaling. Jurnal Skala Husada Apr 2014;11(1):41-5.

3. Nadiawati RP. Efek aplikasi gel ekstrak kulit manggis (Garcinia Mangostana L.) terhadap kepadatan serabut kolagen pada proses penyembuhan luka gingiva (kajian pada Rattus Norvegicus). Minor thesis. Yogyakarta: Universitas Gadjah Mada, Indonesia; 2013.

4. Setianing Y. Pengaruh obat kumur ekstrak kulit manggis (Garcinia Mangostana L) terhadap jumlah koloni bakteri cairan sulkus gingiva pada pasien gingivitis. Minor thesis. Yogyakarta: UGM; 2015.

5. National Institute of Health Research and Development (NIHRD). Indonesia basic health research (RISKESDAS) 2007-2008. Jakarta: Ministry of Health Republic of Indonesia; 2008.

6. Jurnal Kedokteran Gigi [homepage on internet]. Informasi seputar kesehatan gusi; c2012 [cited 2012 Nov 21]; [about 5 screens]. Available from: http://www. jurnalkedokterangigi.com/post/read/483/ informasi-seputar-penyakit-gusi.html

7. Yulia AR. Pengaruh ekstrak kulit buah manggis (Garcinia Mangostana L.) terhadap jumlah fibroblas pada gingiva tikus wistar jantan pasca induksi Porphyromonas Gingivalis, Minor thesis. Jember: Universitas Jember; 2013.

8. Arini NW, Astuti SAPD, Nahak MM. Efektivitas kumur-kumur air rebusan kulit buah manggis pasca oral fisioterapi untuk penyembuhan gingivitis. Jurnal Skala Husada Apr 2014;11(1):6-10.

9. Torres-Lagares D, Gutierrez-Perez JL, HitaIglesias P, Magallanes-Abad N, Flores-Ruiz R, Basallote-Garcia M, et al. Randomized, Doubleblind study of effectiveness of intra-alveolar application of chlorhexidine gel in reducing incidence of alveolar osteitis and bleeding complications in mandibular third molar 
surgery in patients with bleeding disorders. J Oral Maxillofac Surg Jun 2010;68(6):1322-6. DOI: 10.1016/j.joms.2009.08.022.

10. Nakatani K, Nakahata N, Arakawa T, Yasuda $\mathrm{H}$, Ohizumi $\mathrm{Y}$. Inhibition of cyclooxygenase and prostaglandin E2 synthesis by gammamangostin, a xanthone derivative in mangosteen, in $\mathrm{C} 6$ rat glioma cells. Biochem Pharmacol Jan 1, 2002;63(1):73-9.

11. MardawatiE, Filianty F, MartaH. Kajian aktivitas antioksidan ekstrak kulit manggis (Garcinia Mangostana L) dalam rangka pemanfaatan limbah kulit manggis di Kecamatan Puspahiang Kabupaten Tasikmalaya. Jurnal Teknotan 2008;2(3).

12. Nurchasanah. Khasiat sakti manggis tumpas berbagai penyakit. Jakarta: Dunia Sehat; 2013. p. 84-5

13. Agni N. Respons antiinflamasi ekstrak kulit buah manggis (Garcinia Mangostana L.) terhadap jumlah limfosit pada gingiva tikus wistar jantan pasca diinduksi. Minor thesis. Jember: Universitas Jember; 2013.

14. Putri Fl. Respons antiinflamasi ekstrak kulit buah manggis (Garcinia Mangostana Linn) terhadap jumlah sel neutrofil pada gingiva tikus wistar jantan pasca diinduksi oleh Porphyromonas Gingivalis. Minor thesis. Jember: Universitas Jember; 2013.

15. Newman MG, TakeiHH, KlokkevoldPR, Carranza FA. Carranza's clinical periodontology. $12^{\text {th }}$ ed. Philadelphia: Saunders-Elsevier; 2014. 